${ }^{3}$ Horwitz DL, Kuzuya H, Rubenstein AH. Circulating serum C-peptide; a brief review of diagnostic implications. $N$ Engl J Med 1976;295:207-9.

${ }^{4}$ Heding LG. Radioimmunological determination of human C-peptide in serum. Diabetologia 1975;11:541-8.

${ }^{5}$ Heitz PU, Kloppel G, Hacki WH, Polak JM, Pearse AGE. Nesidioblastosis: the pathologic basis of persistent hyperinsulinaemic hypoglycaemia in infants. Diabetes 1977;26:632-42.

- Pagliara AS, Karl IE, Haymond M, Kipnis DM. Hypoglycaemia in infancy and childhood. Part II. J Pediatr 1973;82:558-77.
${ }^{7}$ Milner RDG, Wirdnam PK, Tsawakas J. Quantitative morphology of B, A, D and PP cells in infants of diabetic mothers. Diabetes 1981;30:271-4.

${ }^{8}$ Hollands E, Giron BJ, Reyt F, Dutrillaux MC. Insulin secretion by human pancreas cultured for one year. J Physiol (Paris) 1976;72:815-32.

Correspondence to Dr C G D Brook, The Middlesex Hospital, London W1N 8AA.

Received 28 June 1984

\title{
Neonatal fat embolism and agglutination of Intralipid
}

\author{
M Z MUGHAL, M J ROBINSON, AND W DUCKWORTH \\ Departments of Neonatal Medicine and Biochemistry, Hope Hospital, Salford
}

\begin{abstract}
SUMmary Pulmonary fat embolism in a preterm infant receiving Intralipid intravenously is described. Serum obtained at the time of clinical deterioration agglutinated Intralipid. This coincided with the onset of septicaemia and with a raised serum $C$ reactive protein concentration. Subsequent clinical improvement was associated with reduction in the $\mathrm{C}$ reactive protein concentration and nonagglutination of Intralipid.
\end{abstract}

Intravenous infusion of Intralipid (Kabi-vitrum) has been widely used as a calorie rich supplement and a source of essential fatty acids in intravenous feeding regimens for neonates. ${ }^{1}$ Fat embolism, however, has been found at necropsy in the lungs of infants who have died while receiving intravenous Intralipid. ${ }^{2}$ Hulman $e t a l^{4}$ noted that serum of ill adult patients with a raised concentration of $\mathrm{C}$ reactive protein agglutinated Intralipid in vitro and have suggested that this is the mechanism for lipid microembolisation in vivo.

\section{Case history}

A boy weighing $800 \mathrm{~g}$ was born vaginally at 26 weeks' gestation. He developed hyaline membrane disease requiring intermittent positive pressure ventilation and thereafter required prolonged mechanical assistance for apnoea. The infant was fed parenterally via peripheral veins using a mixture of $10 \%$ Intralipid; Vamin-Glucose (Kabi-vitrum); and $10 \%$ dextrose with electrolyte, trace metal, and vitamin additives. Intralipid was administered by continuous infusion over 20 hours using a syringe pump. Fat intake was initially started at $0.5 \mathrm{~g} / \mathrm{kg} /$ day and subsequently increased to a maximum of 4 $\mathrm{g} / \mathrm{kg} /$ day. Serum was examined visually four hours after stopping Intralipid infusion to confirm clearance of Intralipid.

While on continuous positive airways pressure on day 41, the infant's general condition deteriorated; there was temperature instability and an increase in oxygen requirement for which intermittent positive pressure ventilation was instituted. At the time, fat globules were identified in a tracheal aspirate on Sudan III staining. Pulmonary lipid microembolisation was suspected and intravenous feeding was stopped. Naso-jejunal feeds were introduced cautiously after 48 hours. Blood cultures taken at the time of the deterioration grew Candida albicans and treatment with intravenous amphoteracin and miconazole was begun. There was rapid improvement in the child's respiratory status, with reduction in both the oxygen requirement and the need for ventilatory support, and by day 49 he was extubated into an oxygen enriched environment.

Blood was drawn on days $14,41,45,48$, and 54 of life. The serum concentration of $C$ reactive protein was assessed using rocket immunoelectrophoresis technique. ${ }^{5}$ Ten $\mu$ l of Intralipid $10 \%$ was incubated at $37^{\circ} \mathrm{C}$ with $200 \mu \mathrm{l}$ of serum and the mixture was inspected after 24 hours for visual and microscopic evidence of agglutination. ${ }^{4}$ The findings are displayed graphically in the Figure. The serum concentration of $C$ reactive protein was $2 \mathrm{mg} / \mathrm{l}$ on day 14 ; on day 41 at the time of clinical deterioration and the observation of fat globules in the tracheal aspirate the concentration was $150 \mathrm{mg} / \mathrm{l}$. The candida septicaemia responded to treatment and the concentration of $\mathrm{C}$ reactive protein fell steadily to 7 $\mathrm{mg} / \mathrm{l}$ on day 54 . Serum obtained when the child was ill and when the $\mathrm{C}$ reactive protein concentration 


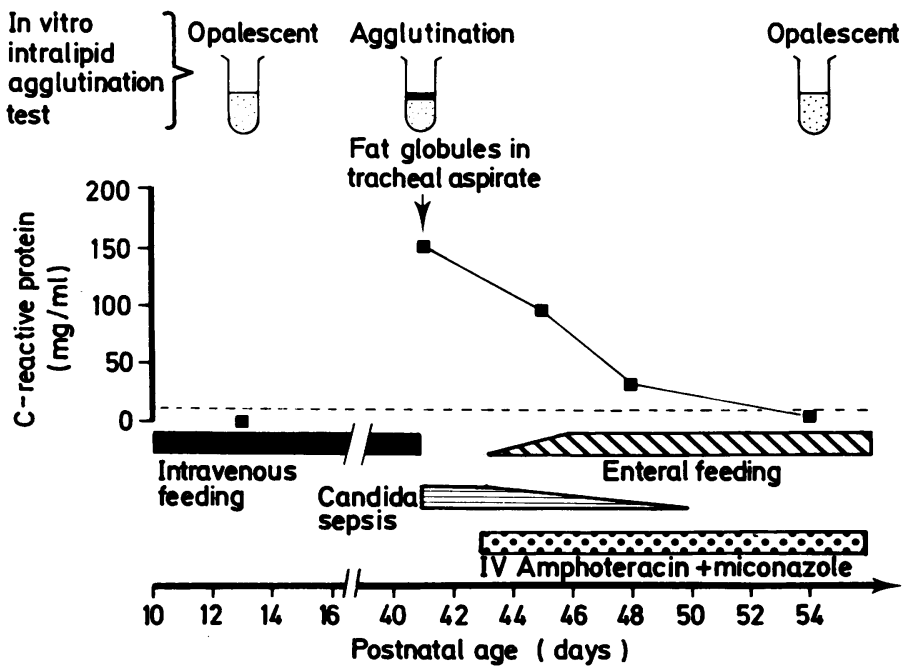

Figure In vitro agglutination of intralipid and serum $C$ reactive protein concentrations during candida septicaemia. was at the maximum value of $150 \mathrm{mg} / \mathrm{l}$ caused in vitro agglutination of Intralipid. On day 14 before the episode of presumed sepsis and on day 54 after its successful treatment, the concentrations were low $(2 \mathrm{mg} / \mathrm{l}$ and $7 \mathrm{mg} / \mathrm{l}$, respectively). On neither of these occasions did in vitro agglutination of Intralipid occur. The infant was discharged on day 114 .

\section{Discussion}

In this infant an increase in oxygen requirement necessitating ventilatory support coincided with the presence of fat globules in the tracheal aspirate. In their account of post-traumatic fat embolism in children Weisz et al include fat excretion in sputum and hypoxia among the diagnostic signs, and we suggest that pulmonary fat embolism contributed to the observed clinical deterioration of our patient.

Sabel $e t a l^{7}$ have found a raised serum $C$ reactive protein concentration to be a useful indication of neonatal sepsis. The $C$ reactive protein value in our patient rose at the onset of candida septicaemia and fell to a normal value (0 to $10 \mathrm{mg} / \mathrm{l})$ after specific parenteral antifungal treatment was begun. In vitro agglutination of Intralipid was observed when the $\mathrm{C}$ reactive protein concentration was at its peak and this coincided with the clinical suspicion of pulmonary fat embolism. In vitro agglutination of Intralipid was not observed when the concentrations were low, that is before onset of septicaemia and after successful treatment. Those infants previously described, ${ }^{2}{ }^{3}$ with necropsy evidence of pulmonary fat embolism had all been very ill; many, as in this patient, with septicaemia. Although Intralipid has been of undoubted value in the management of sick neonates we believe our observations support the view of
Hulman et $\mathrm{l}^{4}$ who postulate that $\mathrm{C}$ reactive protein may be causally implicated in Intralipid embolism in sick patients. It is feasible that the raised $\mathrm{C}$ reactive protein concentration was merely an epiphenomenon, and the observed agglutination was due to an interaction between candida and Intralipid. The results of present studies make this an unlikely explanation but further research will be necessary to exclude this possibility.

We thank Dr A J Barson, St Mary's Hospital, Manchester for helpful advice and constructive criticism; Medical Illustration Department, Hope Hospital; and Mrs Mary Maclean for secretarial assistance.

\section{References}

1 Cashore WJ, Sedaghatian MR, Usher RH. Nutritional supplements with intravenously administered lipid, protein hydrolysate and glucose in small premature infants. Pediatrics 1975;56:8-16.

2 Barson AJ, Chiswick ML, Doig MC. Fat embolism in infancy after intravenous fat emulsions. Arch Dis Child 1978;55:218-23.

${ }^{3}$ Levene MJ, Wigglesworth JS, Desai R. Pulmonary fat accumulation after intralipid in the preterm infant. Lancet 1980;ii:815-9.

${ }^{4}$ Hulman G, Fraser I, Pearson HJ, Bell PRF. Agglutination of intralipid by sera of acutely ill patients. Lancet 1982;ii:1426-7.

5 Laurell CB. Quantitative estimation of proteins by electrophoresis in agarose gel containing antibodies. Ann Biochem 1966;15:45-52.

6 Weisz GM, Schramek A, Abrahamson J, Berzilai A. Fat embolism in children: tests for its early detection. J Pediatr Surg 1974;9:163-7.

${ }^{7}$ Sabel KG, Hanson LA. The clinical usefulness of C-reactive protein (CRP) determinations in bacterial meningitis and septicaemia in infancy. Acta Paediatr Scand 1974;63:381-8.

Correspondence to Dr M J Robinson, Department of Neonatal Medicine, Hope Hospital, Salford 6.

Received 29 May 1984 